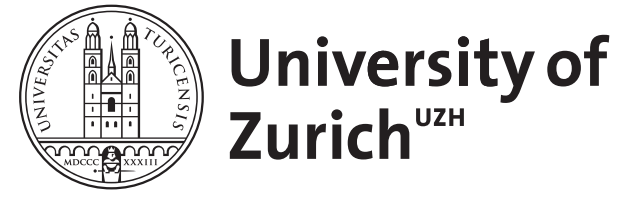

\title{
Possible sulfadoxine-pyrimethamine resistance in Plasmodium falciparum malaria from Kenya
}

\author{
Markwalder, K A ; Meyer, H E
}

DOI: https://doi.org/10.1016/0035-9203(82)90301-7

Posted at the Zurich Open Repository and Archive, University of Zurich ZORA URL: https://doi.org/10.5167/uzh-155528

Journal Article

Published Version

Originally published at:

Markwalder, K A; Meyer, H E (1982). Possible sulfadoxine-pyrimethamine resistance in Plasmodium falciparum malaria from Kenya. Transactions of the Royal Society of Tropical Medicine and Hygiene, $76(2): 281$

DOI: https://doi.org/10.1016/0035-9203(82)90301-7 


\section{Reference}

Cavanaugh, D. C., Fortier, M. K., Robinson, D. M., Williams, J. E. \& Rust, J. H. (1979). Application of the ELISA technique to problems in the serologic diagnosis of plague. Bulletin of the Pan American Health Organization, 13, 399-402.

Accepted for publication 1st November, 1981.

Possible sulfadoxine-pyrimethamine resistance in Plasmodium falciparum malaria from Kenya

Resistance of Plasmodium falciparum to treatment with a combination of sulfadoxine and pyrimethamine ('Fansidar') has been reported from South-East Asia and Brazil, as shown by the CENTER FOR DISEASE CONTROL (1980), FERNEX (1981), HOEFLER (1980), HOLZER et al. (1980), HURWITZ et al. (1981) and RUMANS et al. (1979). We have recently seen a patient returning from Kenya who failed to respond to this drug combination.

A previously healthy 35 -year-old white man, who had never been to the tropics before, spent a huliday in Kenya from May 1st to May 16th. From the beginning, and continuing after his return to Switzerland, he regularly took 'Fansidar' for malaria prophylaxis, one tablet weekly. At the end of May, still under 'Fansidar' prophylaxis, he developed fever and his physician, a specialist in tropical medicine, diagnosed falciparum malaria. The patient was treated with 3 tablets of 'Fansidar' (sulfadoxine 1.5 g/pyrimethamine $75 \mathrm{mg}$ ). For a concomittant urinary tract infection cotrimoxazole was prescribed. All symptoms subsided and the patient continued to take one tablet of 'Fansidar' weekly.

On July 2nd, the patient again experienced an attack of fever and headache and subsequently every evening for seven days. He did not consult a physician again until July 10th, when he developed severe confusion and had to be admitted to the hospital.

On admission, he was prostrated and severely disorientated. The temperature was $39 \cdot 6^{\circ} \mathrm{C}, \mathrm{BP} 120$ / 70 , pulse rate $88 / \mathrm{min}$. Otherwise the clinical examination revealed no particular findings. The thick and thin blood films showed trophozoites of Plasmodium falciparum (parasite density less than 1\%). Haemoglobin was $12.4 \mathrm{~g} / \mathrm{dl}$, erythrocytes $3.92 \times 10^{12} / 1$, WBC $2.3 \times 10^{9} / 1$, platelets $101 \times 10^{9} / 1$. Creatinine and GOT were normal.

Treatment was started with quinine, by intravenous drip for the first 24 hours and then continued orally for 10 days at a dose of approximately $22 \mathrm{mg} / \mathrm{kg} /$ day. Definite fever and parasite clearance occurred after 48 hours, and the patient has remained well up to date.

We had no possibility of more specific laboratory investigations. The question, therefore, remains open, if we were in fact dealing with a true 'Fansidar' resistance of $P$. falciparum, or if the obvious treatment failure was the consequence of poor bioavailability or abnormally rapid metabolism of the sulfonamide. The possible relevance of such factors has been shown by TRENHOLME et al. (1975) and WILLIAMS et al. (1978). The fact that the patient was not cured by a rather high dose of 'Fansidar' (prophylactic plus curative dose) and coincidentally received another antifol combination (cotrimoxazole) makes the former more probable.

Medical Policlinic,

\section{K. A. MARKWALDER}

Department of Internal Medicine,

University Hospital,

CH-8091 Zurich, Switzerland

Gsteigstrasse 30

H. E. MEYER

CH-8049 Zurich, Switzerland

\section{References}

Center for Disease Control (1980). Plasmodium falciparum malaria contracted in Thailand resistant to chloroquine and sulfonamide-pyrimethamineIllinois. Morbidity and Mortality Weekly Report, 29, 493-495.

Fernex, M. (1981). Urgent need to develop new antimalarials. Schweizerische Rundschau für Medi$\operatorname{zin}(P R A X I S), 70,1025-1032$.

Hoefler, W. (1980). Sulfadoxin-Pyrimethaminresistente Falciparum-Malaria aus Kambodscha. Deutsche Medizinische Wochenschrift, 105, 350-351.

Holzer, B., Keller, H., Frossard, E. \& Stürchler, D. (1980). Ist Plasmodium falciparum, der Erreger der Malaria tropica jetzt auch gegen Fansidar resistent? Schweizerische Medizinische Wochenschrift, 110, 324-328.

Hurwitz, E. S., Johnson, D. \& Campbell, C. C. (1981). Resistance of plasmodium falciparum malaria to sulfadoxine-pyrimethamine ('Fansidar') in a refugee camp in Thailand. Lancet, $i, 1068$ 1070.

Rumans, L. W., Dennis, D. T. \& Atmosoedjono, S. (1979). Fansidar resistant falciparum malaria in Indonesia. Lancet, ii, 580-581.

Trenholme, M. G., Williams, R. L., Frischer, H., Carson, P. E. \& Rieckmann, K. H. (1975). Host failure in treatment of malaria with sulfalene and pyrimethamine. Annals of Internal Medicine, 82, 219-223.

Williams, R. L., Trenholme, G. M., Carson, P. E., Frischer, H. \& Rieckmann, K. H. (1978). The influence of acetylator phenotype on the response to sulfalene in individuals with chloroquineresistant falciparum malaria. American foumal of Tropical Medicine and Hygiene, 27, 226-231.

Accepted for publication 29th November, 1981.

The behaviour of Glossina morsitans morsitans near roads

During wet and dry seasons of 1976 and 1977 thè behaviour of Glossina morsitans morsitans was studied along a $10 \mathrm{~km}$ stretch of dirt road passing through Copaifera mopane woodland near Kakumbi, Eastern Zambia, just outside the Luangwa Valley National Park. Many species of tsetse-hosts abound there including elephant, hippopotamus, buffalo and 